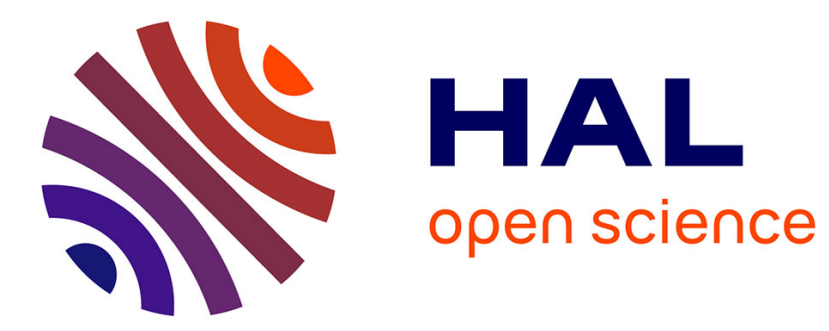

\title{
The traumatic potential of nursing home admission
}

\author{
M. Dreux Dreux Linhardt, Christelle Viodé
}

\section{To cite this version:}

M. Dreux Dreux Linhardt, Christelle Viodé. The traumatic potential of nursing home admission. Psychodynamic Practice, 2020, 26 (2), pp.174-182. 10.1080/14753634.2019.1688918 . hal-03506763

\section{HAL Id: hal-03506763 \\ https://u-bourgogne.hal.science/hal-03506763}

Submitted on 2 Jan 2022

HAL is a multi-disciplinary open access archive for the deposit and dissemination of scientific research documents, whether they are published or not. The documents may come from teaching and research institutions in France or abroad, or from public or private research centers.
L'archive ouverte pluridisciplinaire HAL, est destinée au dépôt et à la diffusion de documents scientifiques de niveau recherche, publiés ou non, émanant des établissements d'enseignement et de recherche français ou étrangers, des laboratoires publics ou privés. 
This is an Accepted Manuscript of an article published by Taylor \& Francis in

Psychodynamic Pratice on 07/11/2019, available at https://www.tandfonline.com/doi/full/10.1080/14753634.2019.1688918

\section{The traumatic potential of nursing home admission}

\section{Dreux LINHARDT*}

Corresponding author, Dreux_Linhardt@etu.u-bourgogne.fr

Université Bourgogne Franche-Comté, Laboratoire Psy-DREPI (Psychologie : Dynamiques RElationnelles et Processus Identitaires), EA 7458, Département de Psychologie, Pôle AAFE, Esplanade Erasme, 21000 Dijon, France.

Centre hospitalier de La Guiche, le Rompoix, 71220 La Guiche, France.

\section{Dr. Christelle VIODÉ}

Université Bourgogne Franche-Comté, Laboratoire Psy-DREPI, EA 7458, Département de Psychologie, Pôle AAFE, Esplanade Erasme, 21000 Dijon, France. 
Imagine for just a moment that you are an 85-year-old woman, widowed a few years ago. You have three, maybe four, children that you reared while taking care of day-to-day housework and doing a couple of odd jobs. Your home has been yours for at least 30 years, and your children or maybe the home care workers come by to help you throughout the day. Until now, you have managed well enough on your own: flowers decorate your balcony, friends come by for tea, and you go out weekly to play scrabble.

Except that today, you are in the hospital in a geriatric ward surrounded by "old people". If only you had not fallen during the night getting to the bathroom. At least you had a couple of hours to admire the tiling one last time, waiting for the neighbors to hear you shouting. One last time, because your children are afraid you will fall again if you ever go back home. You might crack your skull and not just your hip. Moreover, the care provided by the hospital shows you cannot be left on your own: the nurses' aides help you to wash; you only walk with the physiotherapists; the nurses take care of your medication, and the psychologist's evaluation of your memory is less than stunning.

It would seem that you are the perfect candidate for a nursing home though it may not go as well as planned.

This fictional example is heavily inspired by the common trajectories of many of the patients encountered in clinical practice in nursing homes and rehabilitative units. Their experiences lead to questions concerning the psychological impact of nursing home admission.

The following article will begin by expounding a view of psychological trauma before addressing how the elderly are particularly vulnerable to it, specifically when admitted to nursing homes. It will follow by showing how nursing home admission, a seemingly commonplace event, can lead to numerous psychopathological symptoms in residents. To finish, some clinical psychology research aiming to explore the experiences of older adults confronted with nursing home admission will be presented. 
Definitions of trauma can differ. As Pai, Suris, and North (2017) point out, the Diagnostic and Statistical Manual of Mental Disorders, Fifth Edition defines trauma as:

"actual or threatened death, serious injury, or sexual violence" (p. 271). Stressful events not involving an immediate threat to life or physical injury such as psychosocial stressors (e.g., divorce or job loss) are not considered trauma in this definition.'

Nonetheless, daily clinical observations show that other stressful events such as illnesses, falls, and separations can have significant traumatic potential. As such, the same conclusion as Briere and Scott (2006) has been reached and the importance of each individual's subjective experience must be emphasized:

'Our own conclusion is that an event is traumatic if it is extremely upsetting and at least temporarily overwhelms the individual's internal resources.'

Psychodynamic authors such as Freud (1989a), Laplanche, Pontalis, and Lagache (2014) and Chertoff (1997) define trauma in a similar manner as developed by Roussillon (2002) in a modern theorization. The overloading of the individual's adaptive abilities leads to a halt of the symbolizing function of the psyche. One result of this is the repetition compulsion as the psyche tries to symbolize the event piece by piece (Roussillon, 2012).

For Mrs. D., admission to a nursing home meant separation from her home, a house built with her husband whose passing more than 30 years ago is still as painful today as it was then. Each encounter with the psychologist evokes a recount of her 'accident': the fall in her yard that led to her admission, as well as a series of other traumatic events such as a surviving a terrorist bombing and the violent death of her brother. Assessment shows that her cognitive abilities are average for someone of her age and level of education. A thematic apperception test reveals neurotic functioning and obsessive traits. It would seem that the repetitive recall of her past traumas cannot be credited to impaired cognitive function and finds its roots in psychic processes attempting to integrate her life experiences.

As such, trauma results from the encounter between one event or a series of significant events and the current psychological state of an individual:

- $\quad$ The event must arise suddenly or at a time when the individual has 'lowered his guard'.

The event's impact must be significant enough to overwhelm the individual's adaptive resources: '..anxiety is no longer protective but overwhelming' (Bouychou, Costantino, \& Platiau, 2013). 
- Non-mature psychological functioning, through young age or developmental issues, reduces possible defence mechanisms and increases the risk that an event could cause trauma.

- Individuals are particularly vulnerable to trauma at certain stages of life such as adolescence, mid-life or old age, even more so when the traumatic event resonates with the psyche's current struggle such as identity, self-esteem, existential meaning, or death. 


\section{Vulnerability and the elderly:}

As Messy (2010) illustrates, aging is a lifelong process that includes loss as well as gain. Through the first two decades of life, motor function and language develop; object relations come and go, and young adults acquire autonomy while moving away from a facilitating or unsafe primary environment to lead their own lives. Throughout life, each stage contains its own gains and losses.

Elderliness, on the other hand, is clearly the realm of loss: work and the social roles that go with it, health, independence, sometimes spouse or home, and in the end, life. All of these are things that many people admitted to nursing homes have lost, sometimes all at once. To be old, to perceive oneself as such, is to reach the point where losses start to outweigh gains. Dibie-Racoupeau and Granet (2010), as well as Polard (2007), have shown that the awareness of this is often abrupt, coming to consciousness through a specific event such as a fall. Defence mechanisms, overt in clinical encounters with nursing home residents, help them avoid consciously acknowledging their elderliness in order to reduce psychological pain. Such individuals, some more than 90 years old, rarely define themselves as 'old people'. The 'old people' are the other residents they meet in the home, some of whom are 10 or 20 years younger than they are. It would seem, that like death, old age is something that most people can see happening to others but not to themselves. While Freud (2001) believed that it is impossible to imagine one's own death, another view is that such a thought generates considerable anxiety as well as the defence mechanisms to reduce anxiety. The image reflected by the other residents threatens to contaminate the ego-ideal, that which one would wish to be (Akhtar, 2018), by the vision of a hideous-ego, that which one cannot stand to be (Messy, 2010).

Such is the case for Mrs. L. for whom every other resident is an annoyance and in whom she cannot recognize herself. In her words, they are ugly, smell foul, or carry disease. The staff and institution are viewed as persecutory: she doesn't fall, they push her; the food is disgusting, maybe even poisoned. Magical thinking helps her keep death anxiety at bay: those who fall ill and die could have lived if only they had taken better care of themselves, if the doctor had come earlier, or if they had lived in a different nursing home. That is the most important strategy keeping her anxieties in check, the hope of moving to a different, ideal, nursing home, one where, in her phantasy, the food is wonderful, the staff caring, and, above all, no one dies. 
Mrs. $D$ also refuses to recognize herself as one of the residents of the nursing home, the 'grannies' as she says. She is not here because she is ill or dependent such as they but because of her 'accident'. The psychic wounds that her fall and subsequent separation from her home left revive the physical ones that have healed long ago. Her body feels a physical pain in place of the emotional pain her mind cannot bear.

While the awareness of elderliness is often abrupt, it is not always traumatic. Nonetheless, it does not take much for such an event to overwhelm the individual's symbolizing resources.

Additionally, one must not forget that a large majority of the elderly present a specific vulnerability: decreased cognitive abilities. Indeed, research by Corrada, Brookmeyer, Paganini-Hill, Berlau, and Kawas (2010) shows that the number of people with dementia increases with age, doubling every 5 years from age 65 and reaching nearly $40 \%$ among centenarians.

Impaired thought processes, inherent in these conditions, are an additional obstacle to the symbolization function and prevent the individual from making these events their own (Louchard Chardon \& Morhain 2018). For these individuals, events such as nursing home admission can more easily be traumatic. Such trauma, in turn, hinders psychic and cognitive functioning, as they are not efficiently metabolized by intrapsychic processes.

The failure of symbolization can be observed through these individuals' frequent behavioral expressions of psychological suffering. That which cannot be symbolized, thought or said is expressed through gestures, attitudes, or opposition. Biological needs, as well as feelings and emotions, can no longer be put into words and are put into action. Those with advanced neurodegenerative diseases wander endlessly, scream, grab passersby as ways to relieve anxiety or to find someone to comfort them.

Mrs. P's sister would visit once or twice a week with little reaction from Mrs. P. After her sister's death, when the visits stopped, Mrs. P. began wandering around the memory care unit every evening. In her world, something was always amiss; she had forgotten the children at school, the cows were still in the fields and hadn't been milked; the meal wasn't ready for her guest. While she couldn't express her feelings about the loss of her sister, something of her grief resonated with past fears. 


\section{The trauma of nursing home admission:}

For the woman from the introduction, a mundane and recurring event in a wellknown and safe place suddenly becomes traumatic. Subsequently, the failures of the aging body, projected onto the environment to protect self-esteem, will transform this environment into something foreign and threatening. It may no longer offer sufficient support and some patients report strong anxiety when considering the return home after hospitalization as illustrated by Talpin (2017). Unconscious expressions of this anxiety can be seen through parapraxes such as falls and the apparent psychosomatic decline of physical condition that sometimes prevents what seems to be otherwise healthy individuals from going back home.

Events as in the introduction bring back the awareness of one's limited time on earth: extremely short if help doesn't arrive in time and still relatively close even if it does. While for some, such a close encounter with death can be an awakening experience (Yalom, 2009) and foster personal growth, it still generates considerable anxiety and can lead to trauma.

The regained awareness of mortality, manifested in reality and no longer only imagined, resonates strongly with the questions surrounding death that preoccupy the elderly. As a consequence, phantasy and reality seem to collide as the transitional area collapses (Janin, 2015). This can lead to the quasi-psychotic fear, or primitive agony (Winnicott, 1974), that thoughts, phantasies or anxieties might be able to directly manifest themselves in reality.

The subject's transitional area no longer fulfills one of its roles as a buffer or protective shield (Freud, 1989b) between internal and external realities and where both are, at least temporarily, possible.

The usual paradoxical state of the transitional area which allows progressive realityacceptance (Winnicott, 2005), through symbolization processes, is flooded by the rapid ingress of reality and comes to a halt. 
Just as weaning babies must go through a gradual disillusionment of their infantile omnipotence, older humans must gradually let go of their phantasies of immortality if they wish to come to accept the reality of death without being submerged by anxiety.

Following an event as in the introduction, and to avoid its reoccurrence, the person may be admitted to a nursing home. If elderliness begins after an insuperable loss no longer compensated by an acquisition, then, for some, admission to a nursing home is the culminating point of loss in old age.

A case study by Fourques (2013) illustrates what many new residents experience:

'Mrs. R's psychic temporality seems frozen as if the traumatic effect of her admission to the nursing home has robbed her of the sense of self-continuity. She no longer has a past for she does not care for a future here. Facing a future that frightens her is impossible, as it would mean facing the fear of death.'

Despite the best efforts to hide it, death remains ubiquitous in the nursing home environment and the minds of its residents. Solomon, Greenberg, and Pyszczynski (2016) have shown how such mortality salience generates death anxiety. The traumatic experience of nursing home admission as well as the associated injury to self-esteem weakens adequate defence mechanisms and allows anxiety to run free. A review by Iverach, Menzies R.G., and Menzies R.E. (2014) shows that an increase in death anxiety worsens psychopathological symptoms such as anxiety, depression, or obsessive and somatic symptoms, all of which are common among nursing home residents.

The elderly, still at home or in hospital and waiting for admission, often compare nursing homes to other places of reduced freedom such as prisons or the military. One who comes to a nursing home will find a world upon which they have little control: schedules for grooming or eating are preset, opportunities to exercise one's autonomy rare, and little by little social and family roles fade. Dependency increases while the sense of agency declines. Nursing homes are very much total institutions (Goffman, 1961). Living in such a place induces cumulative grief and impacts self-esteem. Research by Kuhnel, El Iraki, Tranchant, and Aspe (2010) shows that up to 50\% of nursing home residents in France present depressive symptoms. This is corroborated by our preliminary research in which $80 \%$ of newly admitted residents ( 3 to 8 weeks post-admission) present at least mild depressive symptoms according to the short form geriatric depression scale (Sheikh \& Yesavage, 1986). These seem to diminish at 6 months post-admission. 


\section{Ongoing research:}

As has been shown, moving to a nursing home is not a trivial event. Such an event becomes traumatic when certain objective aspects of reality encounter other aspects of the individual's subjectivity.

Our clinical experience with older adults has led to three main questions:

- How can the admission process facilitate or impede adaptation to this new place of living? Subject involvement in the admission process seems to increase acceptation whereas families or institutions sometimes choose to hide the truth about admission. The older person may be told it is temporary and that they will go back home soon. This overtly delays the new resident's grief while covertly reducing the family's or institution's feelings of guilt. Nonetheless, by hiding the truth, families and institutions run the risk of generating something close to betrayal trauma (Reyes, Elhai, \& Ford, 2008).

What manners of psychic functioning are predictive of adaptation to life in nursing homes? Contrary to what one might believe, research by Turner, Tobin, and Lieberman (1972) has shown that characteristics usually considered pathological in a community setting such as aggression, narcissism, distrust of others or low empathy may be helpful for life in nursing homes as they allow residents to preserve self-esteem and obtain what they need from the institution.

- How do the subject's internal representations of the institution, the caregivers and the other residents influence their integration? For Mrs. L, splitting and projection transformed these representations into those of a bad object (Spillius, Milton, Garvey, Couve, \& Steiner, 2011). While this protected her from her fears it also sentenced her to a life of isolation.

Through interviews, projective tests, as well as personality, cognitive and depression scales, the study of the interactions between these three aspects of nursing home admission, may show how they might generate trauma and lead to psychopathological symptoms among newly admitted residents.

Primary results seem to show that passive personality traits help residents accept living in a place that manages almost every aspect of their daily lives while more authoritarian personalities can insist on getting what they want from the institution. 
On the other hand, for those that have built their lives around an ideal of independence and individual success, nursing home admission is a narcissistic wound that leads to depressive affect and compensatory defense mechanisms. 


\section{Conclusion:}

As populations continue to age, nursing home admission concerns an increasing number of people throughout the world. Such an event can be traumatic, generating an array of psychopathological symptoms, even more so for the many individuals faced with impaired cognitive functioning

Encounters with older people have led to research into the contributive aspects of nursing home adaptation. While admission is rarely a choice for those facing illness and increased dependency, many individuals manage to rebuild 'good enough' lives within their new homes.

The hope is that this research will lead to a deeper knowledge of the psychology of nursing home admission and thus allow the elderly to be better accompanied through this process. 
Disclosure of interest:

The authors report no conflicts of interest.

\section{Word Count}

2873 


\section{Bibliography:}

1. Akhtar, S. (2018). Comprehensive Dictionary of Psychoanalysis. London, England: Routledge.

2. Bouychou, M., Costantino, C. \& Platiau, J. (2013). Introduction. Cliniques, 5, (1), 1422. doi:10.3917/clini.005.0014.

3. Briere, J., \& Scott, C. (2006). Principles of trauma therapy: A guide to symptoms, evaluation, and treatment. Thousand Oaks, CA, US: Sage Publications, Inc.

4. Chertoff J. (1997). Psychodynamic assessment and treatment of traumatized patients. The Journal of psychotherapy practice and research, 7(1), 35-46.

5. Corrada, M. M., Brookmeyer, R., Paganini-Hill, A., Berlau, D., \& Kawas, C. H. (2010). Dementia Incidence Continues to Increase with Age in the Oldest Old The 90+ Study. Annals of Neurology, 67(1), 114-121. http://doi.org/10.1002/ana.21915

6. Dibie-Racoupeau, F. \& Granet, C. (2010). Les personnes âgées difficiles: un regard gérontopsychiatrique. L'information psychiatrique, volume 86 , (1), 9-14. doi:10.3917/inpsy.8601.0009.

7. Fourques, C. (2013). Quand l'identité s'enfuit, l'effraction surgit: le Moi auxiliaire au service du Moi effracté chez une femme de 91 ans. Cliniques, 5, (1), 72-87. doi:10.3917/clini.005.0072.

8. Freud, S., Strachey, J., \& Strachey, A. (1989a). Inhibitions, symptoms, and anxiety. New York, NY, US: Norton.

9. Freud, S., \& Strachey, J. (1989b). Beyond the pleasure principle. New York, NY, US: Norton.

10. Freud, S., Strachey, J., Freud, A., Strachey, A., \& Tyson, A. (2001). The standard edition of the complete psychological works of Sigmund Freud. Vol. 14. London, England: Vintage.

11. Goffman, E. (1961). Asylums: Essays on the social situations of mental patients and other inmates. Oxford, England: Doubleday (Anchor).

12. Iverach, L., Menzies, R. G., \& Menzies, R. E. (2014). Death anxiety and its role in psychopathology: Reviewing the status of a transdiagnostic construct. Clinical Psychology Review, 34(7), 580-593. doi:10.1016/j.cpr.2014.09.002

13. Janin, C. (2015). Figures et destins du traumatisme. Paris, France: Presses universitaires de France.

14. Kuhnel, M.-L \& El Iraki, I \& Tranchant, M \& Aspe, G. (2010). Prévalence de la dépression en EHPAD : nécessité d'une approche gérontopsychiatrique. NPG Neurologie - Psychiatrie - Gériatrie. 10. 10.1016/j.npg

15. Laplanche, J., Pontalis, J., \& Lagache, D. (2014). Vocabulaire de la psychanalyse. Paris, France: Presses universitaires de France. 
16. Louchard Chardon, C. \& Morhain, Y. (2018). Tyrannie et soumission dans les liens avec le sujet âgé dément. Cliniques, 16(2), 100-113. doi:10.3917/clini.016.0100.

17. Messy, J. (2010). La personne âgée n'existe pas: Une approche psychanalytique de la vieillesse. Paris, France: Payot.

18. Pai, A., Suris, A. M., \& North, C. S. (2017). Posttraumatic Stress Disorder in the DSM-5: Controversy, Change, and Conceptual Considerations. Behavioral Sciences, 7(1), 7. http://doi.org/10.3390/bs7010007

19. Polard, J. (2007). La difficulté de vieillir. Le Journal des psychologues, 246, (3), 4546. doi:10.3917/jdp.246.0045.

20. Reyes, G., Elhai, J. D., \& Ford, J. D. (2008). The encyclopedia of psychological trauma. Hoboken, NJ, US: Wiley.

21. Roussillon, R. (2002). Jalons et repères de la théorie psychanalytique du traumatisme. Revue Belge de Psychanalyse, 40, 24-42.

22. Roussillon, R. (2012). On souffre du non approprié de l'histoire: on guérit en l'intégrant. Le Carnet PSY, 167(9), 36-41. doi:10.3917/lcp.167.0036.

23. Sheikh, J. I., \& Yesavage, J. A. (1986). Geriatric Depression Scale (GDS): Recent evidence and development of a shorter version. Clinical Gerontologist: The Journal of Aging and Mental Health, 5(1-2), 165-173

24. Solomon, S., Greenberg, J., \& Pyszczynski, T. A. (2016). The worm at the core: On the role of death in life. London, England: Penguin Books.

25. Spillius, E. B., Milton, J., Garvey, P., Couve, C., \& Steiner, D. (Eds.). (2011). The new dictionary of Kleinian thought. New York, NY, US: Routledge.

26. Talpin, J. (2007). La crise de la fin d'hospitalisation en gérontopsychiatrie. L'information psychiatrique, volume 83(9), 767-774. doi:10.3917/inpsy.8309.0767.

27. Turner, B. F., Tobin, S. S., \& Lieberman, M. A. (1972). Personality Traits as Predictors of Institutional Adaption Among the Aged. Journal of Gerontology, 27(1), 61-68. doi: 10.1093/geronj/27.1.61

28. Winnicott, D. W. (1974). Fear of breakdown. International Review of PsychoAnalysis, 1(1-2), 103-107.

29. Winnicott, D. W. (2005). Playing and reality. London, England: Routledge.

30. Yalom, I. D. (2009). Staring at the sun: Overcoming the terror of death. San Francisco, CA, US: Jossey-Bass. 